\title{
Reanimating Lost Landscapes: Bringing Visualisation to Aboriginal History
}

\author{
PETER READ
}

Tn volume eleven of Public History Review, Peter Osborne called for 1 the methodologies of environmental history to be brought more securely and more imaginatively into public history. ${ }^{1}$ Environmental history by its own definition, he argued, encompassed Indigenous, ethnic and Anglo-Celtic histories, and heritages natural and built, material and intangible. I believe too that we public historians need to incorporate changing landscapes and topographies as a vital element in understanding why communities and their built heritages constantly transfigure. Sometimes a single geographic factor such as the northern Gulf Stream can go far to explain the spectacular rise of a small island like Great Britain to world power. Equally we can help to explain the precipitous decline of a town like Bourke by degradation and siltation in the Darling River. 
Thinking through the implications of topography even within a city as intensely urbanised as Sydney can be enlightening. The first route from the first settlement to Botany Bay followed the ridgeline of South Dowling Road, not, as one might imagine, the more direct route through what were once the Redfern swamps and lagoons. ${ }^{2}$ It is difficult for road travellers on modern motorways and bridges to conceive how differently Sydneysiders as well as Aborigines used the river system to get about, and how great the journey could be shortened through a knowledge of wind, tide and currents. To float in sly grog in the 1790s and 1800s up the Hawkesbury River and the now little-frequented Marramarra Creek seems today an improbable proceeding, until one realises the comparatively short, convenient and unobtrusive foot track from the creek's limit of navigation to the Windsor point of sales. Most historically minded people could guess that the river flats of Parramatta were more suitable for agriculture than the Sydney sandstone, inviting the colony's second settlement, and they can understand the way the Pacific Highway follows the ridgelines, without which road transport would have been much more challenging. It makes historic sense that the Centennial Park and Sydney's Sports ground complex are built on the infertile remains of the great sand dunes once stretching far north into Queensland. But it is more rather more difficult to understand the disposition of Aboriginal pre and post-invasion settlements of the Sydney region because road engineering increasingly ignores what were, to footwalkers, very serious considerations.

The lengthy and roundabout - but comfortable - motorway route from Mittagong via Prospect to the Blue Mountains can lead us to imagine that was way people always travelled. Yet the Gundangara people associated with the Burragorang Valley had close connections with their kinsfolk living in what became known as the Gully near Katoomba. They walked there on tracks associated with the Cox River valley, now flowing into the Burragorang Dam. From the Katoomba region they connected with their kinsfolk living on the western plains, again through walking tracks of which the Six Foot Track to Jenolan Caves is now a part. It may seem surprising that some of the Aboriginal children in Macquarie's school at Blacktown came from Guringai (Kuringai) speaking country near Sydney's north coast, until one realises how common it was for Aborigines - and everyone else - to use water routes to move about colonial Sydney. 
Yet we public historians working with museums, monuments, oral history and material heritage sometimes don't work in the interpretation of historical topography as much as we might. Investigation of a farmstead and its surroundings should involve a good knowledge of soils, imported weeds and their effects, contour lines, watercourses and abandoned roads to understand how it functioned as a working farm. Thus while carrying out a heritage survey of the route of a projected power line between Armidale and Texas, Queensland, I came upon abandoned cottages in seemingly improbable places, a barely-discernable track which research showed to have been a link on a principal north-south Cobb and Co Coach line, and a Chinese-built irrigation dam in an area where water no longer flowed. To make informed and contextualised conservation recommendations on the most desirable route I needed several weeks' work in the forgotten histories of prickly pear eradication and the declining fortunes of the tobacco industry before I could be confident that I had researched sufficiently the relationship between the route's topography and its historical land use.

It should be obvious that understanding the history of the environment, then, is fundamental to public historians engaged in heritage interpretation. The University of Sydney project, 'A History of Aboriginal Sydney', answers the challenge in seeking to demonstrate as well as explicate the reasons why Indigenous history developed as it did. Very often such explanations rely on topographical data. For example, at least half a dozen Aboriginal town camps flourished well into the twentieth century, as well as dozens of smaller family groups, of which today La Perouse is the only survivor.

One, at Sackville Reach on the Hawkesbury River, was on its own legally declared reserve, but most were traditional gathering places, unsanctioned but to a point tolerated by local councils, just one of perhaps a dozen former stopping places within the group's former walkabout. For varying reasons these camps coalesced into semipermanent, then permanent town camps until engulfed, at different points in the twentieth century, by the ever-hungry Sydney development. Sackville Reach was abandoned by its inhabitants in the 1930s. ${ }^{3}$ The Gully at Katoomba was demolished for a racing car track. ${ }^{4}$ The Aboriginal town camp at the end of Narrabeen Lagoon became a Fitness Centre. ${ }^{5}$ Several reserves in the Burragorang Valley 
were inundated in the 1950s by the construction of the Burragorang Dam. ${ }^{6}$

The town camps came into existence, flourished, and were abandoned or destroyed. We know when and why, and sometimes we know where the people went. But the public with whom public historians communicate also ask more subtle and complex questions requiring us to turn again to topography and environmental history. Why, for instance, given the destruction of the many large and small town camps, especially after the Second World War, were some town camps allowed to survive for so long? Historians in the 1990s and 2000s found that using aerial photography of familiar landscapes with Aboriginal participants greatly expanded their understanding of Indigenous land-use and movement. These included the creative and exciting 'lifestyle biographies' created by Rodney Harrison among the 'Lamboo mob' in Western Australia in which each informant was given a separate layer on the GIS database and the information of each recorded separately. ${ }^{7}$ Excellent work carried out by Denis Byrne and Maria Nugent on the central coast revealed and mapped swimming and fishing spots, and tracks and pathways often now inaccessible or unknown to younger relatives. ${ }^{8}$

Our project, 'A History of Aboriginal Sydney', is identified as historyofaboriginalsydney.edu.au. ${ }^{9}$ Currently it focuses on Sydney's northern coastal region, but within two years we plan to depict and explain the Indigenous land-use of the whole of the urban area since 1788. Through its design the website emphasises place and location. On the interactive time-line we have correlated information on historic individuals with tags like 'Routes and pathways' and 'Sites: historic'. We found that a useful way to digitally convey a connection between a person and a person and a location, or to highlight the location itself, was by means of an interactive map of the north coastal region, with GPS pins locating significant Aboriginal historic sites. Indeed, of all the techniques I have discussed so far GPS site correlation seems the most logical and accessible method of sharing urban Aboriginal history where site-specificity is the first requirement. Google Earth and GPS mapping present an instant view of topography as it is today. Aerial surveys of the Sydney of past decades, of which there are several, can help to indicate what it was.

\section{THE NARRABEen TOWn CAMP}


One important Aboriginal town camp in the twentieth century was at the western end of the Narrabeen Lagoon 33"43'11.84 S 151 "16'03.49E. ${ }^{10}$ The website digital 'pin' describes the site thus:

Current identification: Sydney Academy of Sport The site was the last community Aboriginal town camp to survive in the northern Sydney suburbs. Probably, before the British invasion, Narrabeen Lagoon was one of the many coastal occupation sites offering seasonal shelter, fish and wetland resources. Until perhaps 1850, the western end of the Lake was a community and secular living area standing in relation to the higher country of the Collaroy plateau above. This higher and less accessible country was used for ceremonial and educational purposes by the Gai-Mariagal (Camaraigal) people. Dennis Foley, a descendant, describes the area as 'the heart of our world'. ${ }^{11}$

During the nineteenth and twentieth centuries most of the other northern town camp sites were resumed for housing or recreation by state and shire governments. Similar sites at Quakers Hat Bay, Mosman and Brookvale were probably gone by 1930 . The Narrabeen site survived longer because of its inaccessibility, and was not seriously threatened until the opening of the Wakehurst Parkway in 1946.

By the end of the Second World War the Narrabeen Lagoon town camp had become a more or less permanent refuge for Koori people having kin connections throughout the north-coastal areas, as well along the Hawkesbury River. Dennis Foley, a remembers visiting the site with his uncles or mother in the later 1950s, by which time perhaps fewer than twenty people were in permanent residence. Often his mother brought a bag of flour or a cake.

During the 1950s a fifty hectare site was developed as the National Fitness Centre, including several ovals, a shooting range and accommodation for more than fifty people. The town camp was seen as having no value, and in keeping with the assimilationist thrust of the day, 
the humpies were destroyed and the people forcibly trucked to the western suburbs.

No signage today records the presence of the camp within what is now the Sydney Academy of Sport. ${ }^{12}$

The camp was cleared and destroyed only in 1959. So an immediate historical puzzle is: why was the Narrabeen town camp allowed to survive until then, when so many others similar had gone decades before?

Comparing the satellite images of Google Earth with the aerial photographs of the 1930s and the 1950s, interesting though they may be, do not explain the camp's 1959 longevity, though a close comparison of vegetation and housing development may offer some hints. Nor can maps and photographs illustrate relationships to the Narrabeen/Collaroy non-Aboriginal people who purchased the Kooris' marine produce and sold them their material needs. The aerial photographs and cadastral maps used as the most advanced tools in understanding environmental history only five years ago leave much unexplained.

\section{FROM 2D TO 3D}

Web 2.0, which began to be used widely from about 2004, makes possible most of the modern computer applications such as Google Earth, Facebook and Twitter. It also allowed users into the new field of 3D historical re-creation known more commonly as 'visualizations'. There are hundreds of such examples on the web, from walking tours through ancient Rome to a depiction of land-use along the course of an ancient river in what is now the English Channel. The popular archaeological TV show Time Team used the technology to re-create longhouses, even lost villages, for which sometimes only partial or even implied foundations remained. Despite a number of practical and ethical concerns - in many visualizations it is sometimes not obvious, for example, which are the extant physical remains and which are recreations - the possibilities for pubic historians are intriguing. Indeed, it has been claimed that the introduction of the computer to historical studies may be as critical a watershed as textual deconstruction. ${ }^{13}$

Applying GIS and other forms of spatial data opens exciting possibilities for the deployment of $3 \mathrm{D}$ visualization to aboriginalhistoryofsydney.edu.au in digitally reconstructing some of the 
now-destroyed and lost Aboriginal town camps of Sydney. Thomas has noted that:

Extending historical GIS, they [historians] might attempt to create 'lost landscapes' in ways that fully allow readers to move and navigate through them. These four-dimensional [in the sense of 3D plus temporal change] models might restore buildings, roads, and dwellings to historic landscapes ... Readers might do more than query the datasets; they might interact with them too, taking on roles and following paths they could not predict but cannot ignore. ${ }^{14}$

Even more recently, scholars have begun to see the potential of GIS learning as more than just a medium of education or entertainment.

By visualizing the Narrabeen town camp in four dimensions (that is, the marine environment in three dimensions, plus a representation of temporal change) we hope in this way to incorporate anthropological, historical, sociological, environmental, oral and photographic data to our website. Visualization promises a research tool which texts, oral histories, re-enactments, aerial photography and maps, even when combined, do not necessarily afford. By understanding how, why and where the people lived, where they came from and how they travelled within a single location, researchers may begin to predict the locations of other sites, and why they, too, were abandoned or destroyed. Visualization promises a research tool which descriptive text alone does not afford. As Martyn Jessop argues, 'Of far greater importance is the ability of these tools to allow visual perception to be used in the creation or discovery of new knowledge. ...[K]nowledge is not transferred, revealed or perceived, but is created through a dynamic process. ${ }^{15}$

\section{Creating knOWLedge}

Historical visualisation, then, can create as well as impart knowledge. In this way the History of Aboriginal Sydney team plans a progression from two-dimensional actuality to three-dimensional historical reconstruction. It seems particularly important for a site like Narrabeen where the lack of information about the camp in the usual local sources like council meeting minutes and local papers, is even more acute than in urban Aboriginal history generally. 
In the database from which the reconstruction can be created, we have some oral history. Dennis Foley, who as we have seen was a regular visitor as a young boy, came to the site a few days after its destruction in 1959:

Uncle Gar came out here to talk to the old fellers to see about going fishing. Anyway he come home and there were tears rolling down his face and he just said, 'It's all gone ... It was all bulldozed, they've bulldozed everything, it was just bits of tin'. The huts were built out of odd bits of tin, kerosene tins all flattened out, all this here was bulldozed, all the trees were bulldozed, all levelled, all this was bulldozed, all the trees were bulldozed down and all just smoke and glass and just where the fires had been, all gone. We came back a couple of days to see if anyone had run away, up in the hills, but they were all gone. ${ }^{16}$

Now to animate the historic landscape by considering which of the visualized topographical elements will be most helpful in enabling users to answer the puzzle of why the camp survived until 1959. We need, first, a view of the lake from the viewpoint of the Wakehurst Parkway, which descends the plateau from Oxford Falls, and closely follows the northern edge of the Lagoon all the way to Narrabeen township. For this we will need a very dense series of photographic images of landscape, sometimes through 360 degrees, as the traveller proceeds and, as it were, looks in all directions. What, though, does the 1950s traveller see? To recreate the Lagoon scenery we need to visually create ('texture') the trees, bushes, creek, sandy beach, sandstone escarpment and wind on the water; we need to model and texture any huts or humpies revealed in historic aerial or other views. Our designer will need to animate tidal flows, vegetation sometimes waving in a breeze and changes in mangrove growth and siltation, to produce a half-size storyboard animation, and a third stage with full frame, textured and composted animation with camera movement. The work is likely to represent at least 650 production-hours, and cost more than $\$ 40,000$.

The area now digitally animated, we now attempt to answer our question. Firstly - could the Kooris be seen by passers-by? Immediately noticeable on the re-creation will be that from its nearest 
point on the bumpy track of the Wakehurst Parkway - the camp is out of sight! We can calculate that from the view today, and from a 1943 aerial photo, that travellers on the Wakehurst Parkway would have been able to see no more than a few huts holding fishing gear on the strand, and boats pulled to the shore. Dennis Foley's memories confirm that the Narrabeen Kooris, as other Sydney peoples, preferred to live in rocky caves for security and protection. Looking from the opposite direction, from the escarpment towards the road, the simulated Aboriginal viewpoint reveals that the cave-dwelling Kooris could clearly see any traveller or visitor who could not, by any means, see them. An animated trip in a 1950's 'putt putt' boat across the 1950s-configured lagoon, will replicate how Kooris travelling to Narrabeen township could avoid any non-Aboriginal houses on the lakeside if they wished. A simulated view looking west from the eastern end of the Lagoon, that is, from the centre of the nonAboriginal population towards the camp, will make it immediately plain that the Narrabeen town camp was one of the most hard to see, remote and inaccessible, of all the unsanctioned Aboriginal Sydney town camps of the twentieth century. That revelation is by no means obvious on a cadastral map even today.

Though the Narrabeen town camp was predominantly a camp of old people, the wetland to the west and the adjacent Deep Creek to the north were essential for gathering and hunting ducks, eels, fish, prawns, berries, grasses and wildlife. A walk-through recreation will show the area to be unattractive to the Whites of the 1950s, who quite probably would have referred to it as 'the swamp'. Yet simultaneously the animated appearance of edible vegetation, frogs hopping or ducks flapping away will demonstrate its great value to the Koori residents. Finally, the higher plateau country to the west was still visited for spiritual and educational reasons in the 1950s by both the younger residents and their visiting relatives. After fulfilling appropriate protocols and permission from elders, a simulated walking tour up the steep slope of the plateau edge to some of the existing sites will indicate the continuing close economic and spiritual connection of the community to the hinterland.

The visualization, then, will demonstrate the economic life of a community that was partly self-sufficient and partly dependent on a cash or barter economy with the whites. It will reveal its sources of spiritual sustenance and, most significantly, its near invisibility at a 
time when, fortuitously, the area was not wanted by anybody else. Some elements of survival are more difficult to reproduce. What cannot easily be visualized is the support given by members of the outside Aboriginal community (gifts of flour, tea, money), or conversely, the shared despair over lost relatives, the ravages of alcohol and disease, the mourning for lost ways. But through such a visualized topographic understanding, users will be much closer to an intuitive grasp of the social, religious and economic mainsprings of the Narrabeen town camp. Other town Sydney camps pose different historical questions.

The Salt Pan Creek is an important tributary of the Georges River flowing south into the river from the region of Bankstown. Here in the nineteenth and twentieth centuries lived a number of Aboriginal families, some on freehold, though mortgaged, blocks, which made the owners comparatively secure against the unwelcome visits of local Council and Aboriginal Protection Board officials. But by 1945 they were gone for reasons which are not, in this case, mysterious: depression-induced payment arrears, increasing numbers crowding illegally onto nearby crown land, and an expanding white population caused the local Council to evict any community members who remained. So a different question to be set by visualization of the 1920s Salt Pan camp is: why was this place, more than anywhere else in Sydney, the focus of fierce Aboriginal political radicalism for the first two or three decades of the twentieth century?

These are the elements that would need to be part of the visualization design of the 1920s Salt Pan Creek. First is the comparatively small White population along the creek, which can be calculated by council records and aerial photography. Writing of Aboriginal resilience along the river, historians Heather Goodall and Alison Cadzow write: 'So there continued to be areas into which Aboriginal people could move at low or no cost and with open space around the residential areas.' Mortdale and Peakhurst were 'just far enough away from a close police scrutiny to make it a good place for outspoken views, hard drinking and some shady dealings. ${ }^{17} \mathrm{~A}$ related element is the country itself: the arid sandstone escarpments were regarded as useless for farming by everyone except those who regarded it as part of their traditional walkabout. ${ }^{18}$ The waterway was still clear, unpolluted and comparatively free of mangroves. Like the Narrabeen hinterland, the creek environs were prolific. Even young 
boys could earn pocket money by catching prawns and eels, while wallabies and rabbits supplemented a hunting-gathering diet.

So far the historical explanations are close to Narrabeen's, but now we would need to visualize the wildflowers and gumtips flourishing on the sandstone, gathered regularly and sold door to door or in the city markets by the women of Salt Pan Creek. Men made boomerangs as cultural items carved from gathered mangrove wood to sell to tourists at La Perouse, making a much more buoyant cash economy than was possible at Narrabeen. Perhaps most important was the proximity of the La Perouse Aboriginal reserve itself, just a couple of hours' boat ride away down river with a favourable wind and tide. The many people suffering from, or furious about, managerial strictures had an easy option known at few other places in Sydney: to leave the official and sanctioned reserve and join their relatives at the Salt Pan Creek town camp. In this way the more radical and independent minds were the first to gather here, out of the reach of managers and officials. Here lived, or stayed from time to time, the famous radicals of their day - Hugh Anderson, Jack Patten, 'King Burraga' and William Cooper. From La Perouse, too, came Aboriginal Inland Missionaries - the Salt Pan was easy to get to, and they were made welcome. The community regarded the Christian networks as a means to link up other Aboriginal people state wide also protesting and organising against the increasingly oppressive administrative regime. As its reputation grew as a place of security, of free speech and kinfolk, the Salt Pan town camp became a way-station for Koori people from Victoria and elsewhere seeking both a refuge and an audience before taking part in the more public Sydney activities. ${ }^{19}$

Our visualization cannot reflect meaningfully on other elements which gave the Salt Pan settlement its strength: the historical memories shared amongst the kin-group, the feelings of solidarity against a common oppressor, the harmonious relationship with the Whites in the 1920s and in the 1930s. Or can it? These are still early days of historical visualizations. The future is exciting.

\section{ENDNOTES}

${ }^{1}$ Peter Osborne, 'Environmental history method in public history: opportunities and obstacles in south-west Queensland', Public History Review, vol 11, 2004, p128. 
${ }^{2}$ E.W. West, The memoirs of Obed West: a portrait of early Sydney, Barcom Press, Bowral, 1988, p44.

${ }^{3}$ Jack Brook, Shut out from the world, the Sackville Aborigines Reserve and Mission, 1849-1946, Brook, Seven Hills, 1994; James Kohen, Daruganora, Darug Country - the place and the people, Darug Tribal Aboriginal Corporation, Blacktown, 2006.

${ }^{4}$ Dianne Johnson, Sacred Waters: the story of the Blue Mountains Gully traditional owners, Halstead Press, Broadway, 2007.

${ }^{5}$ Dennis Foley, Repossession of our Spirit, Aboriginal History, Canberra, 2001; Peter Read, Belonging, UNSW Press, Kensington, 2000.

${ }^{6}$ Jim Smith, Wywandy and Therabulat: the Aborigines of the Upper Cox River and their association with Hartley and Lithgow, Lithgow District Historical Society, 1990; Smith, 2008.

${ }^{7}$ Rodney Harrison, 'Dreamtime, Old Time, This Time: Archaeology, Memory and the Present-Past in a Northern Australian Aboriginal Community', in Jane Lydon and Tracy Ireland (eds), Object Lessons, Australian Scholarly Publishing, Melbourne, 2005, p246.

${ }^{8}$ Dennis Byrne and Maria Nugent, Mapping attachment: a spatial approach to Aboriginal post-contact heritage, NSW Parks and Wildlife Service, 2004, chapter 7.

${ }^{9}$ I would like to acknowledge the historyofaboriginalsydney.edu.au development team: Julie Janson, Dr Suzana Sukovic, Andrey Inkin, Sheena Kitchener. Grateful thanks also to Professor Dennis Foley and Professor Heather Goodall for additional information and arranging site visits.

${ }^{10}$ Foley, op cit; Peter Read, Belonging, UNSW Press, Kensington, 2000, chapters $1 ; 8$.

${ }^{11}$ Foley, op cit, $47 \mathrm{ff}$.

${ }^{12}$ Sydney Academy of Sport, A History of Aboriginal Sydney (Online). Available: http:/ / historyofaboriginalsydney.edu.au/northcoastal/location/sydney-academy-sport (Accessed 12 December 2010).

${ }^{13}$ Johanna Drucker and Bethany Nowviskie, 'Speculative Computing: Aesthetic Provocations in Humanities Computing', in Susan Schreibman, Ray Siemens, John Unsworth (eds), A Companion to Digital Humanities, Blackwell, Oxford, 2004.

${ }^{14}$ William G. Thomas, 'Computing and the Historical Imagination', in Susan Schreibman, Ray Siemens, John Unsworth (eds), Companion to Digital Humanities, Blackwell, Oxford, 2004.

${ }^{15}$ Martyn Jessop, 'Digital Visualization as a Scholarly Activity', Literary and Linguistic Computing, vol 23, no 3, 2008, pp281-293.

${ }^{16}$ Interview with Dennis Foley, 2010 (Online). Available: http:/ / historyofaboriginalsydney.edu.au/videos (Accessed 12 December 2010).

${ }^{17}$ Heather Goodall and Alison Cadzow, Rivers and Resilience: Aboriginal People on Sydney's Georges River, UNSW Press, Kensington, 2009, p119.

${ }_{18}^{18}$ ibid, pp118-9.

${ }^{19}$ ibid, pp142-7. 